\title{
NOTES FROM THE LIBRARY: MANUSCRIPTS ACQUISITIONS
}

\author{
BY ALBERTC. KING \\ Mr. King is a Manuscripts Librarian and Archivist in Special Collections \\ and Archives, Rutgers University Libraries.
}

The papers of art critic, biographer and novelist Janet Hobhouse (1948-1991) have been added to the Libraries' manuscripts holdings. A native of New York City, Hobhouse was graduated from Oxford University in 1969. She subsequently worked as an editor and also wrote articles on art topics for several magazines. Her first novel, Nellie without Hugo, appeared in 1982 and was hailed as the work of a talented new writer. Her subsequent books Dancing in the Dark (1983) and November (1986) received generally favorable reviews as well. These three novels, set variously in New York and London, explore conflicts between freedom and security in the context of personal relationships. A fourth novel, published posthumously, is the autobiographical Furies, released in 1993. Nonfiction books by Hobhouse include Everybody Who Was Anybody (1975), a biography of Gertrude Stein, and The Bride Stripped Bare: The Artist and the Female Nude in the Twentieth Century (1988). Present in the Hobhouse papers are notes, manuscripts of writings, reviews, correspondence, photographs, appointment books and other documents totaling approximately twelve cubic feet in size. Completing the collection are family photographs and papers of the author's mother, Frances Hobhouse, a New York-based sculptor.

Theatrical papers donated by Paul Foster (RC '54) reflect three decades of his activities as a playwright. Foster is a former president of La Mama E.T.C., the off-off-Broadway venue where many of his earlier plays debuted or were staged. The papers received document the full range of Foster's experimental theater output, from his early one-act plays such as "Hurrah for the Bridge" and "Balls," through the internationally acclaimed Tom Paine and Elizabeth I. The approximately 21 cubic feet of papers consist of a biographical file, 1964-1989; calendars, 1972-1990; address books, 1969-1984 and undated; correspondence, 1963-1993, including letters exchanged with American and European actors, directors, producers, theatrical agents, publishers, and foundation 
and government officials; writings, 1957-1992, including notes, occasional source materials, outlines and other summaries, scripts (draft, rehearsal and final), songs, page proofs and published plays, as well as various essays; a productions file, 1963-1993, including programs and program notes, publicity materials, cast lists, rehearsal schedules and reviews; over 90 theatrical posters, 1964-1988; photographs, 1959-1988 and undated, in part documenting over 40 different productions of Foster's plays; audio and video recordings, 1963-1992; contracts, 19631983; financial documents, 1967-1988; travel documents, 1960-1992, often in conjunction with overseas openings of Foster's plays; memorabilia, 1964?-1979 and undated; and general files, 1961-1993, relating chiefly to the theater.

At La Mama E.T.C., Paul Foster had met and worked with Tom O'Horgan whose notable career as a director and composer is reflected in the contents of O'Horgan's gift to the Libraries of three and one-half cubic feet of papers spanning the years from 1965 to 1991. The papers pertain chiefly to over 40 theatrical productions (as well as several concerts and films) for which O'Horgan served as originator, adapter, director or composer. This documentation varies in form: scripts (some with annotations), music manuscripts, programs and photographs predominate, but cast lists, rehearsal schedules, stage designer's drawings, notes, posters, reviews and videotapes sometimes are present also. In 1965, 1966 and again in 1967, O'Horgan led the touring La Mama Troupe which brought the American experimental theater experience before European audiences. In both Europe and the United States, O'Horgan earned acclaim for his staging of plays such as Tom Paine and Futz! The first musicals which O'Horgan directed were the controversial and groundbreaking Hair: The American Tribal-Love Rock Musical, which opened in 1968, and Jesus Christ Superstar, which opened in 1971. Many of the works that O'Horgan has staged in the intervening years in North America and Europe have been musicals as well, including several for which he also composed the music.

The papers of two authors represented in the Rutgers University Collection of Children's Literature have been augmented by additional donations. Carol Snyder, formerly of Bridgewater Township, New Jersey, has presented seven cubic feet of papers dating from ca. 1977 to 1987. Included are manuscripts of writings (in multiple versions), galley and page proofs, and related notes, critiques and correspondence. The papers pertain to six published books, including three from Snyder's Ike and Mama series relating to a Jewish family living in the South Bronx 
about 1918. An additional five and one-half cubic feet of papers of Barbara Cohen (GSNB '57) have been received as the gift of her estate through Leah Cohen Chatinover. Cohen, who also resided in Bridgewater Township, wrote over 30 books for children and young adults beginning with The Carp in the Bathtub published in 1972. Many of Cohen's works draw upon themes from her Jewish heritage and some of her books are set in New Jersey. The added papers document Cohen's career from 1968 to 1992, with the bulk of the materials falling after 1978. Present are manuscripts of writings (including several scripts), as well as correspondence with other authors, her literary agent and various publishers.

Manuscript holdings which document the lives of New Jersey women have been expanded through the acquisition of twelve cubic feet of records from the Women's Project of New Jersey, Inc. The Project was organized in 1984 to gather and publish information about notable New Jersey women. Following incorporation in 1985, the Project successfully sought grant money to underwrite many of its activities (which also drew upon the talents of dedicated volunteers). Products of the Women's Project of New Jersey included the volume Pastand Promise: Lives of New Jersey Women (1990), a traveling photographic exhibition and the Project's archives. Included in the records of the Project are minutes, 1984-1990, of the board of trustees and of the editorial board; correspondence files, 1984-1990; fundraising files, 1985-1989, including copies of grant proposals; editorial files, 1984-1988, including the manuscript of Past and Promise; and biographical files relating chiefly to New Jersey women born in or before 1923. The biographical files pertain to over 300 people, some of whom do not appear in the published volume. Folders on individual women typically include the Project's standardized data checklist, notes, photocopies of primary and secondary source materials and one or more drafts of a biographical essay. Some women are also represented in the archives by photographs, audio-visual materials or copies of their publications.

Two and one-half cubic feet of records, 1980-1987, of the New Jersey Lesbian and Gay Coalition have been received. The Coalition serves as a "representative forum to unify, encourage, aid and support the efforts of the New Jersey organizations whose purpose is to promote, secure and protect the human dignity, integrity, legal, civil and political rights of all people regardless of their sexual orientation." Established in 1972 as the New Jersey Gay Coalition, the organization adopted its present name in 1983. In addition to press clippings, records in the Coalition's gift include chronological correspondence files, 1980-1984; general files, 
1982-1987, chiefly concerning fund raising, governance and lobbying; production files, 1985-1987, for "News Jersey", the Coalition's newsletter; and files, 1984-1985, pertaining to an AIDS education project in northern New Jersey. Also documented in the records is the Personal Liberty Fund of the Lesbian and Gay Coalition of New Jersey, Inc., which was formed in 1984 as the Coalition's legal defense and education fund.

The New Jersey Water Pollution Control Association has begun donating its archives to the Libraries. A nonprofit organization, the Association seeks to advance "technical and practical knowledge concerning the nature, collection, treatment, conveyance, reclamation [and] disposal of domestic and industrial wastewater and management of hazardous waste." Founded in 1916, the organization, at first known as the New Jersey Sewage Works Association, is the oldest professional society in the country devoted to the control of water pollution. Archival records received from the New Jersey Water Pollution Control Association to date include minutes, 1938-1989, of the North Jersey Section; minutes, 1940-1965, of the Central Jersey Section; and minutes, 19281957, of the South Jersey Section; together with the Association's journal (New Jersey Effluents) and newsletter (SCAN).

Documentation of the iron industry in New Jersey forms a significant theme in a collection of Taylor family papers which has been acquired (Charles H. and Mary Elizabeth Brower, William Allen Chapman and Special Collections Endowment Funds). These papers, which span three generations of a prominent family, date from 1769 to 1882. Andover Furnace (located at Andover) and Andover Forge (located at Waterloo) were superintended for a number of years by Robert Taylor (1742-1821). Present in the Taylor papers are journals, 1773-1777 and 1783-1785, a waste book, 1784-1785, and a ledger, 1785-1788, of Andover Furnace, together with journals, 1782-1786, and ledgers, 1784-1790, of Andover Forge. A related time book, 1786-1794, apparently pertains chiefly to the furnace and includes diary entries recorded by an unnamed superintendent. Papers of Robert Taylor's son Archibald S. Taylor (1780-1860) relate primarily to his financial interests, including a partnership with John W. Bray. Like his grandfather, Lewis H. Taylor (b. 1811) became prominent in the iron industry. In 1851 he revived the forge at High Bridge, Hunterdon County, where the Taylor family had resided for over half a century. Beginning in 1852 High Bridge Forge was operated as G. \& L. Taylor (a partnership of George W. \& Lewis H. 
Taylor), but by 1858 it was conducted under the name of Taylor \& Large (a partnership of Lewis H. Taylor and James K. Large). In 1868 the firm incorporated as the Taylor Iron Works with Lewis H. Taylor as president. Records of this company in the Taylor papers include a ledger, 1851-1852; a daybook, 1852-1854; a cash book, 1858-1863; and Lewis H. Taylor's cash account, 1863-1866, pertaining to the forge. 